\title{
Socio-Economic Analysis of Street Vendors after Relocationin Makassar City (Family Sociology Prospective Study)
}

\author{
Sam'un Mukramin ${ }^{1}$, Fatimah Azis ${ }^{2}$, Maemunah ${ }^{3}$, St. Haniah ${ }^{4}$ \\ ${ }^{1234}$ University of Muhammadiyah Makassar \\ Correspondent: sam un88@yahoo.co.id
}

$\begin{array}{ll}\text { Received } & \text { : August 26, } 2021 \\ \text { Accepted } & \text { : January 15, } 2022 \\ \text { Published } & \text { : January 31, } 2022\end{array}$

Citation: Mukramin, S., Aziz, F., Maemunah., Haniah, St (2022). Socio-Economic Analysis of Street Vendors After Relocationin Makassar City (Family Sociology Prospective Study). Ilomata International Journal of Social Science, 3(1),29-37.

https://doi.org/10.52728/ijss.v3i1.396

\begin{abstract}
This research contributes to knowledge and ideas in improving the welfare of street vendors after relocation due to the construction of a flyover. In addition, the government's alignment with socio-economic income in meeting the livelihoods and livelihoods of marginalized communities still has many limitations. Therefore, the type of research used is a qualitative research which aims to analyze, understand and describe the welfare of the street vendors after relocation. So this study shows that (i) PKL families on Jalan Andi Pangerang Pettarani cannot be said to be prosperous because they have not met the family welfare indicators, such as some families do not have savings have never been on vacation, which is one of the family indicators.
\end{abstract}

Keywords: Prosperous, Welfare, Street Vendors, Role Family

\section{INTRODUCTION}

The family is the smallest unit of society, consisting of a husband, wife and child, father and child, or mother and child. The family is usually also called the household. The term family comes from the language Sanskrit" citizens." The word kula means "race," and warga means "member." A family is an environment where several people are still related by blood (Abdillah, 2019; Azis \& Mukramin, 2020; Purandina \& Winaya, 2020; Sandora, 2020). A family is a group of people who live together in a shared residence, and each member feels an inner connection so that they influence each other, care for each other, and surrender to each other. Apart from that, the family is a group of people who live together in a shared residence. And each member feels their relationship so that there is mutual influence, concern, and mutual surrender. The family is formed through marriage, namely the inner and outer bond of a man and a woman as husband and wife, to create a happy and prosperous family (Kurniati et al., 2020; Maemunah et al., 2021; Solaymani \& Kari, 2014).

Each family member has their role even though they have differences and similarities; generally, fathers and mothers have the same position in nurturing their children. However, there is a slight difference in touch from what father and mother display. A man as a father has a role as the backbone of the family who is obliged to meet household needs. However, along with the 
development of the times, which resulted in the high price of every need, the income of the husband or head of the family was no longer able to meet all the requirements in the family. Thus, other family members, such as housewives who inevitably have to earn a living to maintain their family life (

In informal sector activities such as Street Vendors (PKL), more are chosen by family members who do not have exceptional skills in earning a living to help their families, because among urban problems which until now have not found the right solution in prevention, one of which is poverty and unemployment because of the disorganized form, primarily self-employed, irregular ways of working, self-funded or unofficial sources, so it can be seen how many community members choose the type of this business, because it is easy to use as a job for people of low economic strata that are widely available in our country, especially in big and small cities (Basu \& Nagendra, 2020; Nkosi \& Tabit, 2021; Rofiyanti et al., 2021; Turner et al., 2021).

There are several model communities and forms of trade in Makassar. One of which is the street vendor community located on Jalan Andi Pangerang Pettarani, the Makassar city. As the name implies, this community is active along Jalan Andi Pangerang Pettarani, precisely in the BantaBantaeng village, Rappocini sub-district, Makassar city. The PKL community has been selling in the Andi Pangerang Pettarani street area for decades; they occupy storefronts on the sidewalks along with the Andi Pangerang Pettarani street Makassar city, the types of merchandise also vary. On the one hand, the existence of street vendors is enough to help overcome the problem of unemployment in the City of Makassar and as a source of revenue for the local government of Makassar. But on the other hand, the existence of these street vendors raises several problems.

On the one hand, the existence of street vendors is recognized as an economic potential that cannot be underestimated for being able to absorb labor in large enough numbers and provide the necessities of life for the community. But on the other hand, its existence is considered disturbing the beauty and orderliness of the City's environment that making government have to intervene to overcome this problem. Therefore, government intervention in this case naturally also affects the pattern of life and behavior of street vendors.

Public from the weak economy who work as street vendors aims to gain prosperity in their lives, both family welfare and social welfare. Although the substance remains the same, social welfare has several relatively different meanings. The first conception of social welfare is more appropriate to observe the achievement of family welfare. The point is that social welfare is a condition of life or a state of well-being, namely the fulfillment of physical, spiritual, and social needs.

Thus, the term family welfare is often interpreted as a prosperous condition, namely a condition where all the necessities of life, fundamental ones such as food, clothing, housing, education, and health care, are met. Likewise, with the families of street vendors who are on Jalan Andi Pangerang Pettarani Makassar city, they sell in the hope of making a profit so that the results they get can be used to meet their family needs such as clothing, food, housing, education, health and set aside a little from the profits are in the form of savings, and recreation with the family. Therefore, researchers are interested in researching this subject with the title "Socio-Economic Analysis of Street Vendors Post Relocationin Makassar City (Family Sociology Prospective Study)." 


\section{METHOD}

The type of research used is descriptive qualitative research (Azevedo \& Ferreira, 2013; Bungin, 2017; Creswell, 2017; Sugiyono, 2019). This research aims to analyze, understand and describe the welfare of street vendors' families as well as their functions and roles in the family after the relocation due to the 2017-2020 flyover construction in Makassar City. Informants were determined by purposive sampling, based on the characteristics of the informants that have been selected with a total of ten (10) people consisting of the head of the family or family members who work as street vendors at least one year, both male and female, the village government, There are nine sub-districts and related offices. Data collection techniques are observation, documentation, and in-depth interviews. Data analysis techniques are through the stages of data reduction, data presentation, and conclusion drawing.

\section{RESULT AND DISCUSSION}

\section{The dominance of Women in Domestic and Social Roles}

From the focus of the problem on Jalan Andi Pangerang Pettarani, Makassar city, it is located in Banta-Bantaeng Village with land use including offices, street vendors, education centers, restaurants. The land shift around Andi Pangerang Pettarani's location has undergone drastic changes in the east. The dominant functions of Jalan Andi Pangerang Pettarani are offices and education. The land use pattern at this location has developed according to the demands of increasing economic growth and population growth. It can be seen on the lands around Andi Pangerang Pettarani street; the trade area is growing and rising.

\begin{tabular}{|c|c|c|c|}
\hline No & Gender & Soul & Percent (\%) \\
\hline 1. & Man & 7.213 & 49 \\
\hline 2. & Woman & 7,621 & 51 \\
\hline & Amount & 14,834 & 100 \\
\hline
\end{tabular}

Source: Secondary Data 2020

It is known that the total population in Banta-banteng Village is 14,834 people, the number of men is 7,213 or $49 \%$, and the number of women is 7,621 people or $51 \%$. Therefore, judging from the percentage of the table above, it can be said that the number of women is more than that of men. This will undoubtedly affect the participation of women in working outside the home to meet needs to improve welfare.

Meanwhile, on the other hand, related to the profession of the residents of Banta-banteng Village, Makassar City, including: 


\begin{tabular}{clll}
\hline No. & Type of work & Amount & $\begin{array}{l}\text { Percent } \\
\mathbf{( \% )}\end{array}$ \\
\hline 1. & State Civil Apparatus (ASN) & 984 & 9.85 \\
2. & Retirees (ASN/TNI/POLRI) & 343 & 4.1 \\
3. & Small and medium entrepreneur & 62 & 1.05 \\
4. & TONI & 8 & 0.13 \\
5. & POLRI & 9 & 0.15 \\
6. & Lawyer & 6 & 0.1 \\
7. & Notary Public & 3 & 0.05 \\
8. & Private Lecturer & 10 & 0.17 \\
9. & Government company employees & 530 & 8.94 \\
10. & Freelance & 658 & 11.1 \\
11. & Driver & 30 & 0.51 \\
12. & Consultant & 6 & 0.1 \\
13. & Housewife & 945 & 15.94 \\
14. & Student & 1814 & 30.6 \\
15. & Not working yet & 604 & 10,19 \\
16. & Private & 416 & 7.02 \\
\hline
\end{tabular}

Source: Primary Data 2020

From the table, it is known what the people of Banta-Bantaeng Village carry out types of work. The average potential under the not prosperous line is greater than the already successful. This can be seen in the number of percentages between Small and Medium Entrepreneurs, Lecturers but the private sector, freelance daily workers, drivers, homemakers, students, not yet working and remote workers who do not have a straightforward income with a dominant percentage of 76.58. In addition, for homemakers with a rate of 15.94. This has enormous potential in involving women with dual burden roles. A dual role is when women carry out domestic tasks and social/public functions, including working as street vendors.

Social roles are a set of behaviors expected to motivate someone who occupies a certain social status (Ariccio et al., 2021; Burk \& Wiese, 2018; Ismail et al., 2015; McLeod, 2020). Each social group has the expected function and role related to its interaction with other individuals in the family. For example, a man who is the head of the family is expected to have an instrumental role, namely ensuring survival and protecting his family. In contrast, the status of homemakers has an emotional or expressive role that can give tenderness, affection, and love and, of course, plays a role in the domestic sphere. Social roles are strongly influenced by the cultural norms in which they are located.

The role of the wife in the traditional family concept is only as a housewife, where her job is as a caregiver for children and husbands in taking care of all the needs needed by family members (Azis \& Mukramin, 2020; Chalid, 2015; Solaymani \& Kari, 2014). This is also related to gender roles, where the part of women is to be obedient, and on average, they always have a level of education that is not too high. Very different from the past ten or twenty years where a mother did not play a role in making a living for her family, in the modern era and development 
technology as it is today, everything is very different, and many habits or things appear and disappear. Therefore, a woman can play a dual role in current conditions, not just being a mother who stays at home waiting for her husband and children to come home from daily activities, even though she is a street vendor.

From the information obtained, when he decided to work as a street vendor, he went through a previous socialization process for this job. Therefore, he already had his perception of the position he chose. In some cases, the choice of this job is based on their interest in the work they can do. So with the reason for the selection, the informants shared their interest in the street vendor profession as follows:

\section{a. No Higher Education Required}

Those from the lower class have a relatively small scope of work due to the limited skills and resources. However, the selection of street vendors is considered profitable because this type of work does not require many unique skills and a high level of education so that informants who only have low-quality resources can still enter the job. Of the ten informants, only one person completed education up to the undergraduate level, and four people only completed education up to the elementary school level.

\section{b. No Restrictive Rules}

Regarding the work system, they are going through which they are free to determine for themselves, such as the hours and days they work or sell, because this is related to the dual role that is the responsibility of each informant. Women who work in the public sector and come from the lower classes still have to carry out their dual functions in the domestic industry. This makes the informants think that working as street vendors is very appropriate for them because their working hours can be determined by themselves according to their domestic responsibilities.

\section{c. Small Capital and Easy Work}

The initial capital needed to sell is pretty affordable for informants so that this becomes an attraction for informants to start businesses that aim to improve their economy, not only that profession what they do is relatively easy to do starting from preparing sales, serving buyers and their obligation to clean the area around the place they sell. Carrying out work as a street vendor does not require significant capital and is relatively easy. This work is easy to do by various groups such as married women and those in the lower economic class. Although this job is sometimes threatened with eviction, the income earned is large enough so that the informants continue to sell and support their families.

Family economic conditions that are not so good sometimes force a homemaker to work to earn a living even though she has to leave the children at home and maybe household choresladder so abandoned.

Based on social status, the family is divided into three main structures: father/husband, mother/wife, and children (Azis \& Mukramin, 2020; Farrell et al., 2012; Maemunah et al., 2021). In this structure, each has a social status that gives identity to each individual. For example, the husband/father is the head of the household; the wife is the housewife. Look at the very long working hours, namely taking care of the family and working outside the home, of course. You 
will make women lose their social role as members of the community, like getting involved in inactivityinstitutions at the community level and other social activities in the community. This is not an issue for informants because, for them, the most important thing is how to keep working to meet the family's economic needs. All events and all structures are functional for all societies. As is the case in this study about the problem of a low-income economy, change can occur slowly in the community. As in the social facts, some women work to fulfill the family's economic needs. With the participation of these women in financial fulfillment activities, it is clear that these women are functional for their families because they can help improve their family's economy (Abdillah, 2019; Bungin, 2017; Chalid, 2015; Fathy, 2019; Susanto et al., 2020).

Through functional, structural theory (Mcewen, 2017; Tualeka, 2017), the family is considered to consist of the father, mother, children, and other family members. Each family member has their function. This function brings its consequences for the family, as in this study, which discusses the welfare of street vendors who require other family members such as housewives to make a living. Apart from being at home, they also have to work outside the house to improve their family's economy. So, in this case, it can be seen that the housewife is functional for her family (Barsoum, 2021; Mukramin, 2018; Sekhani et al., 2019).

\section{Functions and Roles of PKL Family Members}

The division of roles is not based on considerations of ability between men and women because men can do all women's work. Still, he chooses not to do it because the position of men or husbands is more respectable in society if the man or husband earns a living for his family. This is because the main task as the head of the family is to make a living for his family, while the main task as a housewife is in the domestic sector. Still, when economic needs increase, homemakers are allowed to work outside the home, but the primary obligation of homemakers remains his household.

A dual role is undoubtedly challenging because you have to manage and divide your time between domestic and public work. The duty of a housewife is essential in maintaining a family where she has to do household tasks such as cooking, washing, raising children, taking care of her husband, and other work done in the house. This domestic work must be done continuously to become important for the family. In addition, the family's economic needs are critical in supporting the family's survival. When these needs are not met will result in the weakening of the family economy. This makes homemakers are encouraged to work outside the home to help their husbands meet family needs, namely daily needs, and future needs (Lata et al., 2019; Martinez \& Rivera-Acevedo, 2018; Prabhu et al., 2019).

When viewed from the informants' daily activities, it can be concluded that the work of homemakers outside the home makes household work slowly shift to other family members. However, this does not change the activities of the street vendors when they return home. Based on the information obtained, it is known that when they have returned home and still have time and energy, they will take the time to do household chores such as cleaning/cleaning the house, washing. This activity they still do before and after they work and is adjusted to their abilities.

The participation of homemakers in earning a living substantially contributes to their families. Improving the family economy can be seen from the ability of the informants to earn income 
that can be used to meet their daily needs and a better life because informants no longer have to go into debt to meet their needs. In addition, the work of homemakers makes an increase in the family's economy. This can be seen from fulfilling their daily necessities such as food, clothing, health, household care, and their ability to pay for their children's education.

\section{CONCLUSION}

Based on the research that has been done, it can be concluded as follows:

1. Although street vendors' families can meet basic needs such as food, clothing, housing, and health, it cannot be said to be a prosperous family because they have not been able to meet social-psychological needs such as recreation and development needs such as savings, both of which are indicators of family welfare.

2. Other family members, such as housewives who work as street vendors, have two roles, namely:

a. First, the role of the public, working as street vendors.

b. The domestic role, being a housewife who has responsibility in doing domestic tasks such as taking care of the household, serving her husband, and raising children. However, with a housewife's work, she is unable to maximize her role as an educator for children.

3. The economic impact felt by the family is an increase in the family's economy, which is marked by the fulfillment of their daily needs and the ability to finance their children's education.

\section{REFERENCE}

Abdillah. (2019). Studi Karakteristik Kehidupan Sosial Dan Ekonomi Pemulung Di Tempat Pembuangan Sampah Akhir (TPA) Kelurahan Tamangapa Kecamatan Manggala Kota Makassar. Jurnal Environmental Science, 2(1). https://doi.org/10.35580/jes.v2i1.11425

Ariccio, S., Lema-Blanco, I., \& Bonaiuto, M. (2021). Place attachment satisfies psychological needs in the context of environmental risk coping: Experimental evidence of a link between self-determination theory and person-place relationship effects. Journal of Environmental Psychology, 78, 101716. https://doi.org/10.1016/j.jenvp.2021.101716

Azevedo, S., \& Ferreira, F. I. (2013). Participation and Learning in a Jenaplan School in the Netherlands: An Ethnographic Research with Children. Procedia - Social and Behavioral Sciences, 82, 599-603. https://doi.org/10.1016/j.sbspro.2013.06.316

Azis, F., \& Mukramin, S. (2020). The Family Decision Making Patterns of Children with Special Needs: a Sociology Study of the Family. Jurnal Pendidikan Sosial Dan Budaya Al Ma'arief, 2(2), 53-59. https://doi.org/10.35905/almaarief.v2i2.1828

Barsoum, G. (2021). From Fisher wives to fish vendors: Gendered livelihood transitions in a fishing village in Egypt. Journal of Rural Studies, 88, 117-125. https://doi.org/10.1016/j.jrurstud.2021.10.012

Basu, S., \& Nagendra, H. (2020). The street as workspace: Assessing street vendors' rights to trees in Hyderabad, India. Landscape and Urban Planning, 199, 103818. 
https://doi.org/10.1016/j.landurbplan.2020.103818

Bungin, B. (2017). Metodologi Penelitian Kualitatif (B. Bungin (ed.); 2nd ed.). PT Rajagrafindo Persada. https://www.rajagrafindo.co.id/produk/metodologi-penelitian-kualitatif-burhanbungin/

Burk, C. L., \& Wiese, B. S. (2018). Professor or manager? A model of motivational orientations applied to preferred career paths. Journal of Research in Personality, 75, 113-132. https://doi.org/10.1016/j.jpp.2018.06.002

Chalid, P. (2015). Teori dan Isu Pembangunan (P. Chalid (ed.); 2nd ed.). Universitas Terbuka. https://pustaka.ut.ac.id/lib/mapu5102-teori-dan-isu-pembangunan-edisi-2/

Creswell, J. W. (2017). Research Design Pendekatan Kualitatif, Kuantitatif, dan Mixed (S. Z. Qudsy (ed.); 3rd ed.). Pustaka Pelajar. https://opac.perpusnas.go.id/DetailOpac.aspx?id=1213690

Farrell, B., VandeVusse, A., \& Ocobock, A. (2012). Family change and the state of family sociology. Current Sociology, 60(3), 283-301. https://doi.org/10.1177/0011392111425599

Fathy, R. (2019). Modal Sosial: Konsep, Inklusivitas dan Pemberdayaan Masyarakat. Jurnal Pemikiran Sosiologi, 6(1), 1. https://doi.org/10.22146/jps.v6i1.47463

Ismail, I., Rahim, N. A., Kamal, M. H. M., Mat, R. C., \& Husin, N. (2015). Investigating the Needs for Achievement, Risk Taking and Tolerance for Ambiguity toward Entrepreneurial Passion among Single Mother Entrepreneur in Malaysia. Procedia Economics and Finance, 31, 110-116. https://doi.org/10.1016/S2212-5671(15)01137-5

Kurniati, E., Nur Alfaeni, D. K., \& Andriani, F. (2020). Analisis Peran Orang Tua dalam Mendampingi Anak di Masa Pandemi Covid-19. Jurnal Obsesi : Jurnal Pendidikan Anak Usia Dini, 5(1), 241. https://doi.org/10.31004/obsesi.v5i1.541

Lata, L., Walters, P., \& Roitman, S. (2019). A marriage of convenience: Street vendors' everyday accommodation of power in Dhaka, Bangladesh. Cities, 84, 143-150.

https://doi.org/10.1016/j.cities.2018.08.002

Maemunah, M., Haniah, S., \& Mukramin, S. (2021). Education Marginalization Of Bajo Children Based On Local Wisdom. International Journal of Educational Research \& Social Sciences, 2(3), 585-591. https://doi.org/10.51601/ijersc.v2i3.80

Martinez, L., \& Rivera-Acevedo, J. D. (2018). Debt portfolios of the poor: The case of street vendors in Cali, Colombia. Sustainable Cities and Society, 41, 120-125. https://doi.org/10.1016/j.scs.2018.04.037

McLeod, S. (2020). Maslow's Hierarchy of Needs. Simply Psychology. https://www.simplypsychology.org/maslow.html

Mukramin, S. (2018). Strategi Bertahan Hidup: Masyarakat Pesisir Suku Bajo di Kabupaten Kolaka Utara. Walasuji: Jurnal Sejarah Dan Budaya, 9(1), 175-186. https://doi.org/10.36869/wjsb.v9i1.29

Nkosi, N. V., \& Tabit, F. T. (2021). The food safety knowledge of street food vendors and the sanitary conditions of their street food vending environment in the Zululand District, South Africa. Heliyon, 7(7), e07640. https://doi.org/10.1016/j.heliyon.2021.e07640

Prabhu, V., Gupta, S. K., Madhwal, S., \& Shridhar, V. (2019). Exposure to Atmospheric Particulates and Associated Respirable Deposition Dose to Street Vendors at the 
Residential and Commercial Sites in Dehradun City. Safety and Health at Work, 10(2), 237244. https://doi.org/10.1016/j.shaw.2019.01.005

Purandina, I. P. Y., \& Winaya, I. M. A. (2020). Pendidikan Karakter di Lingkungan Keluarga Selama Pembelajaran Jarak Jauh pada Masa Pandemi COVID-19. Cetta: Jurnal Ilmu Pendidikan, 3(2), 270-290. https://doi.org/10.37329/cetta.v3i2.454

Rakhmawati, I. (2018). Peran Keluarga dalam Pengasuhan Anak. Jurnal Bimbingan Konseling Islam: Konseling Religi, 6(1), 1-18. https://doi.org/http://dx.doi.org/10.21043/kr.v6i1.1037

Rofiyanti, E., Santiko, A., Susetyo, I. B., Agustina, D., \& Razikin, K. (2021). Local Wisdom And Regional Policy In The Implementation of Friendly Basic Service Covid 19. Ilomata International Journal of Social Science, 2(3), 190-194. https://doi.org/10.52728/ijss.v2i3.295

Sandora, M. (2020). Konsep Pendidkan Anak Marginal Dalam Perspektif Pendidikan Berbasis Masyarakat. Marwah: Jurnal Perempuan, Agama Dan Jender, $18(2), 196$. https://doi.org/10.24014/marwah.v18i2.7588

Sekhani, R., Mohan, D., \& Medipally, S. (2019). Street vending in urban 'informal' markets: Reflections from case-studies of street vendors in Delhi (India) and Phnom Penh City (Cambodia). Cities, 89, 120-129. https://doi.org/10.1016/j.cities.2019.01.010

Solaymani, S., \& Kari, F. (2014). Poverty evaluation in the Malaysian Fishery Community. Ocean \& Coastal Management, 95, 165-175. https://doi.org/10.1016/j.ocecoaman.2014.04.017

Sugiyono. (2019). Metode Penelitian Kuantitatif, Kualitatif, dan R\&D - MPKK (I). Alfabeta. https://cvalfabeta.com/product/metode-penelitian-kuantitatif-kualitatif-dan-rd-mpkk/

Susanto, A., Wahyuni, Mirawati, Muharram, B., Asdar, Taufiq, M., Nasrullah, Nisar, Karim, P. A., Murida, I., Rahma, S., Febri, M. Z., Muliana, M., Nugrahayu, Imran, M. A., Masna, Ilham, Aisyah, N., Karvina, ... Sakti. (2020). Biografi Tokoh-Tokoh Sosiologi: Klasik sampai Postmodern (W. Bakri (ed.); 1st ed.). IAIN Parepare Nusantara Press. https://doi.org/https://doi.org/10.31219/osf.io/5kt8z

Turner, S., Zuberec, C., \& Pham, T.-T.-H. (2021). Visualizing frictional encounters: Analyzing and representing street vendor strategies in Vietnam through narrative mapping. Applied Geography, 131, 102460. https://doi.org/10.1016/j.apgeog.2021.102460 